UDC $81-13$

DOI: $10.17223 / 24109266 / 7 / 7$

\title{
FEATURES OF TRANSLATING ECONOMIC TEXTS FROM CHINESE INTO RUSSIAN
}

\author{
A.E. Malankhanova ${ }^{1}$, P.V. Sysoyev ${ }^{1,2}$ \\ ${ }^{1}$ Moscow Pedagogical State University (Moscow, Russia) \\ ${ }^{2}$ Tambov State University (Tambov, Russia) \\ E-mail: duoniya@gmail.com; psysoyev@yandex.ru
}

\begin{abstract}
This paper considers basic definitions of "discourse" proposed by various scholars and describes institutional economic discourse. On the example of the economic text in Chinese the authors analyze in detail the four groups of signs of institutional discourse (constitutive, institutional; specificity; neutral), and describes the differences in lexical composition, stylistic and syntactic structures used by the speaker, depending on the intentions of a certain economic sector communication. The authors distinguish features of translating texts with an economic discourse from Chinese into Russian, classifies the difficulties in translating the texts and outlines key conditions required for the translation of economic texts. One of the key conditions for successful translation is analysis of the source text as the most difficult stage in translation from Chinese into Russian.
\end{abstract}

Keywords: Chinese language; discourse; institutional signs of economic discourse; translation; economic translation.

\section{Introduction}

Recently, in view of the deepening bilateral cooperation between Russia and China in many areas, attention is given to the active cooperation of Russian and Chinese companies in various fields, especially in trade and the economic sphere. In this regard, there is a need for qualified sinologists and translators who play an important role in the process of negotiating with Chinese partners, building up cooperation and sometimes in making business decisions. For the better training of future translators, there is a need to intensify the learning process as well as search for new methods and ways of teaching foreign languages according to the competence approach in education to meet the requirements of the Federal State Educational Standards of Higher Professional Education and modern standards, including computerization of language education, which is becoming an integral part of the learning process $[1,2]$. The development of new educational programs and rethinking the organization of training arose due to changes in the requirements for future translators, as well as in connection with the social order of society [3]. 


\section{Definition of "discourse"}

The theory of discourse, as one of the most rapidly developing areas in modern linguistics, seeks to unify the scientific results obtained in various fields of knowledge, and primarily in linguistics, psychology, sociology and ethnography. Such sciences as computational linguistics and artificial intelligence, philosophy and logic, anthropology and ethnology, and others also study discourse. Each science's approach to the study of discourse has its own way, but discourse researchers, first of all, seek to "learn not the abstract language system, but live speech in a real dialogue" [4: 4].

Discourse analysis is the linguistic discipline that studies discourse. Discourse analysis as a branch of linguistics and one of the leading multidisciplinary areas studies linguistic communication. Discourse analysis emerged in the XX century against a background of the revision of the philosophical and ontological foundations of all disciplines and the main trend of "cleansing" the science of language from the study of speech [5: 11]. It emerged and developed the view that all linguistic phenomena cannot be adequately and clearly described without discursive aspects. Much attention is paid to the question of language functioning that immanent linguistics cannot answer, which is explained by the expansion of the subject of its study, and increased attention "to the human factor, subjectivity in linguistics" [4: 83].

In order to determine the semantic content of discourse, S.K. Gural [6] examines in detail its basic categories, such as proposition, inference, explicature and implicature, reference, relevance and presupposition as the main guides in discursive analysis.

Many foreign and Russian scholars have studied the concept of "discourse": T.A van Dijk, Deborah Schiffrin, N.D. Arutyunova, A.A. Kibrik, V.V. Krasnikh, Y.A. Prokhorov, V.V. Bogdanov, M.L. Makarov and many others. Researchers define discourse as "speech, the process of languagerelated activities; a way of speaking", a "generic category in relation to the concepts of speech, text, dialogue", etc. $[4,5]$. In modern linguistics "discourse" is referred to real linguistic interaction, the dynamic process of linguistic communication and the result of language activities, i.e. discourse includes text, and the processes of its creation and understanding as developed in time.

N.D. Arutyunova in the linguistic encyclopedic dictionary gives the following definition: Discourse (from the French 'discours' - speech) is a coherent text in conjunction with extra linguistic and pragmatic, sociocultural, psychological and other factors; text taken in the event-driven aspect; speech which is considered as purposeful social action, as a component involved in the interaction of people and mechanisms of their consciousness (cognitive processes). Discourse is the speech "immersed in life" [7]. Ac- 
cording to some scholars discourse is a communicative act and suggests the presence of a speaker and addressee, and the roles between individuals may vary [5: 10]. In this paper we follow the classical definition of "discourse" and understand it as an oral or written communication text used in a particular field of communication, including a combination of linguistic communication means and extra-linguistic factors.

\section{Analysis of an economic text on institutional characteristics}

Since the action and interaction of individuals take place in a specific communication environment, in a particular social field of communication institutional discourse is distinguished, which is opposed to personal discourse. V.I. Karasik developed the idea of the institutional discourse concept, defining it as "samples of verbal behavior established in society, in relation to secured areas of communication" [8]. On the basis of dialogue in the framework of status-role relationships in modern society the following types of institutional discourse are distinguished: political, economic, diplomatic, educational, medical, legal, linguistic and others. V.I. Karasik proposes to distinguish institutional discourse on two grounds: objectives and participants of communication. For example, the purpose of economic discourse can be business correspondence, negotiations, business planning, etc. Participants of institutional discourse are representatives of society - "agents" and "clients" - people who appeal to them [9].

Many studies in the field of institutional discourse are now connected with the sphere of the economy, which is a part of human culture with its specific laws, a sphere of human activity that changes with the development of history, politics, science, and social norms. Following E.Y. Makhnitskaya we also believe that economic discourse is a set of speech acts used in the description and characterization of economic realities: oral and written texts reflecting economic practices [10: 159]. Economic discourse is a special type of discourse in which knowledge about economic realities, properties and qualities of economic phenomena is presented and reported.

Often economic discourse and business discourse are considered to be one and the same. In our view, economic discourse includes business discourse, and has a broader concept. Economic discourse in addition to communication between business representatives, business partners on the foreign market, intergovernmental communications, speeches at economic forums, covers the entire system of communication in the fields of production, exchange, distribution and consumption of goods and services. Among communicants of economic discourse there are not only experts in the field of economics, but also journalists, politicians and ordinary people. Compared to other types of discourse this explains the special status of economic discourse, as in some cases it is difficult to identify the boundaries between political, diplomatic and economic discourse. 
There are four groups of institutional discourse features:

1) constitutive;

2) institutional;

3) specificity;

4) neutrality.

The constitutive group involves participants, conditions, organization, methods and materials of communication. Institutional features include "agents" and "customers" and verbal clichés used by them. The specificity of institutional discourse is conditioned by its type as a specific social institution, and is associated with the specified functions of participants, their behavioral norms, level of culture, education, background knowledge, which are reflected and reproduced in texts. Neutral signs imply general discursive characteristics typical for any other communication, not necessarily institutional, and other elements of discourse [9].

Consider the above group of features in relation to economic discourse on the example of an excerpt from the opening speech of the President of the PRC, Xi Jinping, during the opening of the Boao Forum for Asia (BAF) 2015, in which he focuses on economic issues:

。。。女士们、先生们、朋友们!

中国和东盟国家将携手建设更为紧密的中国一

东盟命运共同体，东盟和中国、日本、韩国致力于 2020 年建成东亚经 济共同体。我们要积极构建亚洲自由贸易网络, 争取在2015年完成中 国一

东盟自由贸易区升级谈判和区域全面经济伙伴矢系协定谈判。在推进 亚洲经济一体化的同时, 我们要坚持开放的区域主义, 协调推进包括 亚太经合组织在内的跨区域合作。

。。中国经济发展进入新常态, 正从高速增长转向中高速增长 , 从规模速度型粗放增长转向质量效率型集约增长, 从要素投资驱动 转向创新驱动。2014年, 中国经济实现了 7.4\%的增长, 劳动生产率提 高了 7\%, 单位国内生产总值能耗下降了 $4.8 \%$, 国内生产总值, 服务业 发展加快, 发展质量和效益不断提高。我们看中国经济, 不能只看增 长率, 中国经济体量不断增大, 现在增长 $7 \%$ 左右的经济增量已相当可 观, 聚集的动能是过去两位数的增长都达不到的。。

。。最后, 预祝年会取得圆满成功! 谢谢大家 [11].

The constitutive features here, first of all, are participants of communication: heads of states, heads of governments, heads of international organizations, ministers, members of the Board of Directors of the BFA, speakers. The sphere of communication is also a vivid example of communication and refers to such features: in our opinion, the purpose of this speech excerpt is to set the "right tone" of the forum and open discussion about the need to 
improve the model of development and adjustment of the economic structure of Asia, stressing the importance of the role that Asia plays in the development of the world economy, especially against the background of the current crisis, to talk about China's economic situation at the end of 2014.

Institutional characteristics of the above speech consist of the characteristics of "clients" and "agents". A communication "agent" is the Chairman of the PRC, who opens up the work of the forum, whose speech contains a considered position on the subject under discussion:

我们要积极构建亚洲自由贸易网络，争取在2015年完成中国一 东盟自由贸易区升级谈判和区域全面经济伙伴矢系协定谈判。在推进 亚洲经济一体化的同时, 我们要坚持开放的区域主义, 协调推进包括 亚太经合组织在内的跨区域合作。

"We want to actively build a network of free trade in Asia, in 2015 to complete the negotiations on the modernization of the China-ASEAN free trade area, and a comprehensive agreement on economic partnership. In order to promote economic integration in Asia, at the same time, we must adhere to open regionalism, to coordinate the promotion of interregional cooperation, including APEC."

"Clients" of communication are all participants of the "round table", that is, people whose kind of occupation is associated with a particular area of the economy. The degree of "openness" of such discourse for professionals is high, because "clients" of the communicative act represent their institutions, and are well-informed on the discussed issues, they can also act as "agents", changing their role position at the forum.

The specificity of the above institutional discourse is represented by its kind: it is a business economic discourse. Lexical features and special terms should be noted: 经济共同体 “economic community”, 贸易网络 “trade network”, 自由贸易区 “free trade zone”, 经济伙伴 “economic partnership", 经济一体化 “economic integration”, 亚太经合组织 “APEC”, 跨区域合作 “interregional cooperation”, 粗放增长 “extensive growth”, 劳动生产率 “work performance”, 国内生产总值 "gross domestic product”, 增长率 "rate of growth".

The neutral group of features is conditioned by the presence of speech cliches. For example, the speech of Xi Jinping starts with an appeal typical for any polite speech in China (女士们, 先生们, 朋友们 - Ladies and gentlemen, friends) and ends with a standardized phrase (谢谢大家 - Thank you for your attention). 


\section{Differences in special institutional signs of economic discourse depending on the field of communication}

Due to the fact that economic discourse covers many sectors of the economy (entrepreneurship, marketing, trade relations, management, etc.), special institutional characteristics of the discourse are different. Depending on the field of communication lexical composition and stylistic format, syntactic constructions used by the speaker are different due to the intentions in this or that sphere of communication. For example, business discourse of people working in a sales department has a high degree of involvement of the speaker in the communication process as the professional interest of the sender is not only to attract the attention of the interlocutor, but also to present their goods in a concise and memorable way. In this case, there is a high degree of emotional color in the communicative act, in which the role of the "agent" is represented by a professional of the sales department and a potential buyer stands as a "client", which, in general, is not peculiar to business communication. So, in lexical terms here epithets, comparisons and a large number of numerals are used; in grammatic - enumeration, a relatively short construction, exclamatory and imperative sentences. For example, the Deputy Director of Sales of "Chery" describes the achievements of the company as follows:

首先我觉得今天这个活动非常有意义，我们的主流媒体、我们的 专业机构开始站出来矢注我们的经销商, 给我们的经销商提供一个畅 所欲言的环境, 我个人认为是汽车整个行业的进步, 并且我们认为是 一个非常好的现象, 只有经销商觉得舒服了、有劲了, 厂家才能干得 好, 我们才能一起为我们的客户服务好, 所以我要在此作为一个普通 的汽车人向我们今天各个主办方表示感谢。

2005 年奇瑞公司累计销售是 18.9 万台车，同比增长 $118 \%$, 应该是在中国十大汽车集团里面增幅最大的, 也是中国乘用车行业里 面第一家一年增幅突破 10 万台车的企业, 并且连续四年创立了汽车的 出口第一。

但是今天奇瑞的销售怎么样不是我要讲的内容, 我要讲的是奇瑞 公司卖的一台车没有一台车是奇瑞公司卖的, 每一台车都是经销商卖 的, 今年 1 月 1 日也是在北京奇瑞公司举行了一个超过 1 千人参加的奇瑞 经销商大会, 当时我们提出了四个口号, 合作、诚信、承诺、未来, 首先要诚信, 这是一个合作之道, 然后要有一个承诺, 在这个基础上 我们要进行合作, 这样大家彼此才有未来 [12].

The speech of entrepreneurs is more restrained, less stylistically and lexically colored, grammatically more structured. So Chinese entrepreneurs describe the difficulties associated with the export of goods to Russia in 
connection with growth of the dollar against the Russian ruble in late 2014 early 2015, which led to difficulties with the procurement of goods in China:

“今年上半年1美元还只能兑换33卢布, 但一眨眼就能换66卢布了 ，已有俄罗斯买家向我们提出推迟提货了。”某大型家电企业俄罗斯市 场负责人称, “客户给不了具体的提货期, 付款也要求推迟。上周六我 们工厂紧急开会, 减少其备货量以防万一 [13].

The economic text is a foundation of scientific and economic discussions in conferences, forums and business meetings, it represents an unlimited diversity of scholarly and analytical texts, media publications, and includes components of informative, argumentative, comparative evaluating statements. Each generated text is unique and narrowly specific depending on the ultimate goal of the speaker and the situation of the communication, which includes all kinds of extra-linguistic factors, but it retains the general characteristics and properties inherent to economic discourse in general: in lexical terms - economic terminology, in argumentative terms - the use of different means of persuasion to solve professional problems. Here is an example from the interview of Tian Gouli, Chairman of the Board of Directors of the Bank of China:

今后我们会继续把这个网络搭建的更强一些。同时我们也会在完 善信息系统、发展网络和物理渠道同电子渠道的互补, 争取打造出 24 小时全球一体化的，高效率金融服务体系 [14].

In this passage a strategy of persuasion is realized by means of such communicative method as persistent use of the pronoun我们 "we" which creates a favorable image of a united, serious team of the bank, which is aimed at improving the efficiency of customer service. In addition, through the use of expressions such as 完善信息系, 高效率金融服务体系 a tactic to create a positive image of the bank is also used.

The style of Chinese economic texts is a complex, multifaceted phenomenon. It should be noted that business economic discourse is a system of "sublanguages" used by experts in various fields - trade, business, management, services, manufacturing, etc. And in each economic area there exists its own "sub-language", elements of which may substitute, exclude, or complement each other. In a specific situation of communication interlocutors will be involved in a new communication space in which they will use, at least a specific set of lexical units, and at most - different speech strategies [15]. Despite the fact that each type of economic discourse has its own communicative specifics, they are all united by common aims, which are professional productive communication, conveying information, resolving the issue in a specific field of knowledge.

It should be noted that through the learning of genre features of economic discourse, knowledge and skills needed to understand and translate 
texts of official business and economic issues from Chinese to Russian are generated. Analysis of economic texts allows us to understand their special forms, the properties that appear in a given communication situation. We can say that institutional economic discourse makes it possible to understand the economic realities that exist both within individual groups (for example, a company) and in economic communication in the framework of one state or interaction of several states. The translation of economic discourse texts from Chinese to Russian should be done taking into account the abovementioned features, i.e. characteristics of institutional discourse shall be taken into account, the actual essence of texts and relevant information shall be precisely and correctly expressed, descriptiveness and expressivity are not forgotten, where they are applicable.

\section{Difficulties arising while translating economic texts from Chinese into Russian}

The problem of translating economic texts in the Russian theory of translation has been much discussed. As noted above, economic texts are characterized by a certain set of lexical, stylistic and syntactic properties. Economic texts are characterized by the use of a special vocabulary, formulae and special speech clichés. The vocabulary of economic texts is represented by a wide range of economic, financial, banking, political and other terms.

Terminological vocabulary occupies a large place in Chinese economic discourse, as terms carry considerably more information than other lexical units, and also occurr in large quantities and represent basic economic concepts. Terms are words and phrases denoting specific objects and concepts which experts use in a specific area of science or technology [16]. That is, a term may be defined and thus has its own definition. Thus, there is a transfer of concepts that are the semantic basis of a statement. But the difficulty of translating economic texts is to give an exact translation of terms provided that concepts are not always the same because of differences. Reference to explanatory dictionaries of Chinese and translation into Russian and English by Chinese translators can help to understand Chinese economic discourse.

For example, consider the term 流动性 “liquidity”, which is a calque word from the English language, because the exact equivalent of an economic concept in the Russian language has not been found. The original meaning of the word "liquidity" is "liquid". At the same time with the meaning of the word in recent years the words "liquidity" and "liquid" are common in the economy as economic terms, and represent different notions, namely: the ability to raise cash quickly and without losses; transferring into money [17]. There may be difficulties in translating this term from Chinese (流动性) because a literal translation means "mobility" and "moveability". In this case, 
we turned to the translation of the word from Chinese into English, where the term means "liquidity".

Similarly, we can consider the terms边际 “marginal”, 保增长 “sustainable economic growth", 现金流 “cash flow”, 套期保值 “hedging”, 配额 "quota" and others.

Terms of two or more words denoting economic terms often cause the greatest difficulty in translation and make it necessary to refer to Chinese economic explanatory dictionaries. Separately, components of such phrases usually do not cause difficulties in translation, and are often used, which leads to difficulties in translation, especially, oral, if the translator does not possess a good knowledge of economics or does not have the practical skill of translating idiomatic phrases.

For example, to perform an adequate translation of the term 次级贷款 “subprime loan” we turned to the "Quick Start Guide of economic terms" by Shen Jie, which provides an interpretation of the term in Chinese: a loan that may be issued by the credit institution to borrowers with an unreliable credit history or low incomes (指一些贷款机构向信用程度较差和收人不高的借款人提供的贷款).

The guide also provides synonyms of the phrase 次级抵押贷款或次级按揭贷款 [18].

The purpose of translating economic texts is to convey the most correct translation in view of the differences existing in the economic realities of different countries. It can be achieved only in the case of detecting equivalent terms, which can cause the most difficulties, as many terms have appeared in Russian relatively recently, many have been borrowed from English and the concepts to which they correspond, in some cases, are not available or are formed in accordance with Russian economic realities.

When translated from Chinese into Russian, the main difficulty lies in the right understanding of the Chinese text. Due to the fact that conditions for economic activity in Russia and China are different, it can be concluded that in some cases it is a difficult task to exactly translate this or that term. Without a deep knowledge of the economic sphere and the features of its use in China the translation of terms from Chinese into Russian will be inadequate to one degree or another.

In stylistic terms, economic texts can be both neutral and expressive. Their syntactic structure, as a rule, is not very complex, so when translating such texts the main changes relate to the fact that the structure of the Chinese sentence, in contrast to Russian, is more rigid and stable, and this is caused by the need to rearrange components of the message. For example:

谈到中俄两国在经贸领域的务实合作, 李辉说, 近年来, 中俄经 贸合作在互利互惠精神指导下不断迈上新台阶, 各方面合作均取得丰 硕成果。 
Referring to the process of business cooperation between China and Russia in the field of trade and economy, Li Hui said that in recent years there has been a continuous improvement in Sino-Russian trade and economic cooperation based on the principles of mutual benefit and having a successful development in all areas of bilateral cooperation.

In this text in the translation into Russian the object "continuous improvement of Sino-Russian trade and economic cooperation" and the predicate "has been" are rearranged. This is due to the fact that "in the Chinese language there is maintained a firm order of subject-predicate-object" [19: 157]. Therefore, if in the Chinese sentence the object takes a position in relation to the predicate, then when translating into Russian it should be rearranged to a postpositional position. In addition, components of the attributive combination "level of Sino-Russian economic and trade cooperation" are also rearranged. The rearrangement of attributive complex components is explained by the fact that in Chinese, in contrast to Russian, one must firstly put the original notion - "Sino-Russian trade and economic cooperation", and then the dependent - "level".

Translation of the attributive combinations from Chinese into Russian often causes errors in the order of the attributive complex components because of the differences in principles of the arrangement of attributive combination components in Chinese and Russian. The structure of the Chinese sentence has a firm order, in which the predicate cannot precede the subject and the object follows the predicate, which also leads to possible errors in translation. The occurrence of these errors is connected to "the presence of the Russian stereotypical thinking, because of which the lexical and grammatical structure of the Chinese language phrase is built on the model of the Russian language" [Ibid: 49]. Therefore, it requires certain skills to perform a grammatical analysis for the proper allocation of these parts of the sentence in order to avoid mistakes in translating the sentence. "Formal and structural analysis when translating from the Chinese language is important for many reasons, also because of the polyfunctionality of lexical units, when only analysis of the word's position in a sentence can afford to refer it to a particular part of speech" [20: 13].

Another feature of the economic discourse of the Chinese language is the use of stable combinations - chengyu "complete expressions", which is a characteristic of the Chinese language. Chengyu is an idiomatic expression, formed over many centuries, however, there are relatively new chengyu since the process of converting new stable combinations is still ongoing [21]. Chengyu are commonly used in speech to enrich the language. The widespread use of chengyu is explained by the fact that because of its conciseness and structure (the most common type of chengyu is quadri syllabic conversion) such expressions can convey a precise meaning. However, the difficulty of translation is that chengyu usually have a figurative meaning, and are 
not literally translated by characters. The following chengyu are often used in everyday speech: 货真价实 “quality at a reasonable price”, 实事求是 "proceed from the real situation, business approach", and others.

Features of translating economic texts from Chinese into Russian

\begin{tabular}{|c|c|c|c|}
\hline № & Features & Characteristics & Difficulties in translation \\
\hline 11 & Lexical features & $\begin{array}{l}\text { Economic vocabulary represented } \\
\text { by a wide range of financial, bank- } \\
\text { ing and other terms, special vocab- } \\
\text { ulary and clichés }\end{array}$ & $\begin{array}{l}\text { High saturation of materials by } \\
\text { new terms, lack of notions in } \\
\text { the Russian language; under- } \\
\text { standing of differences in no- } \\
\text { tions and features of their use } \\
\text { in China; terms of two or more } \\
\text { words, the components of } \\
\text { which are often used and can } \\
\text { cause confusion when translat- } \\
\text { ing phrases }\end{array}$ \\
\hline 22 & Stylistic features & $\begin{array}{l}\text { Have stylistic coloring of a text } \\
\text { depending on the field of commu- } \\
\text { nication, different speech strategies } \\
\text { (engagement of the speaker in the } \\
\text { communication process, a high } \\
\text { degree of emotional color, use of a } \\
\text { large number of comparisons, epi- } \\
\text { thets, numerals, hortatory and ex- } \\
\text { clamatory sentences; use of cheng- } \\
\text { yu }\end{array}$ & $\begin{array}{l}\text { Need to select expressive and } \\
\text { stylistic variants of translation, } \\
\text { to convey the exact meaning } \\
\text { of the original text. Determin- } \\
\text { ing the type of chengyu in } \\
\text { terms of the literal and figura- } \\
\text { tive sense, highlighting them } \\
\text { in the text, and to fully convey } \\
\text { the meaning of statements, } \\
\text { with no loss of conciseness, } \\
\text { and to preserve its integral } \\
\text { meaning in order to avoid } \\
\text { inaccurate or erroneous under- } \\
\text { standing of the entire state- } \\
\text { ment }\end{array}$ \\
\hline 33 & Syntactic features & $\begin{array}{l}\text { Strict word order in the Chinese } \\
\text { sentence structure (positions of } \\
\text { subject and predicate), need to } \\
\text { rearrange components of a mes- } \\
\text { sage in translation. } \\
\text { Use of a large number of combina- } \\
\text { tions in the attributive expressive } \\
\text { texts }\end{array}$ & $\begin{array}{l}\text { For native speakers of Russian } \\
\text { a strict order of words in the } \\
\text { sentence "subject-predicate- } \\
\text { object" is a great difficulty for } \\
\text { translation from Chinese } \\
\text { where the predicate cannot } \\
\text { precede the subject and the } \\
\text { object follows the predicate, } \\
\text { which leads to possible errors } \\
\text { in translation }\end{array}$ \\
\hline
\end{tabular}

Table presents the main features of the translation of economic texts, to which attention must be paid for the successful translation of texts Chinese into Russian. On the basis of the existence of economic discourse, we note that the translation of economic texts has its own specific characteristics and its features of translation. 


\section{Conclusion}

Translation of economic texts from Chinese into Russian is one of the most difficult types of translation. For translation there is a need to meet a minimum number of conditions: foreign language proficiency; knowledge of a certain amount of a foreign language vocabulary (terminology); the ability to use bilingual dictionaries [20]. To master the skills of reading and the translation of economic texts, it is necessary to analyze the original text, and then form this text in Russian. Following V.F. Schichko and G.Yu. Yakovlev, and according to our long-term experience in translation, we also believe that the most difficult and challenging stage in the translation from Chinese into Russian is to analyze the translated text [22]. Since all lexical units of hieroglyphic text - words, phrases, proper names, functional words - are written in hieroglyphs at the same distance, often mistakes can occur in the separation of lexical units, highlighting words, connecting composite lexical units, etc. Then, properly marked lexical units must be translated into Russian. In our opinion, the development of the basic skills of translating economic texts can be carried out through the study of materials from the economic to expand the knowledge of vocabulary and grammar and to form the primary skills of analysis and translation of Chinese economic texts taking into account peculiarities of the syntactic structure of the Chinese sentence and the stylistic coloring of the text.

\section{References}

1. Sysoyev, P.V. (2012) Modern information and communication technologies: didactic characteristics and functions. Language and Culture. 1 (17). p. 120-133.

2. Sysoyev, P.V. (2012) Informatization of foreign language education: main directions and perspectives. Foreign Languages at School Journal. 2. p. 2-9.

3. Gural, S.K. \& Tikhonova, E.V. (2013). Organization of the training process of oral sequential interpretation in the light of the synergetic theory. Language and Culture. 4 (24). p. 77-82.

4. Makarov, M.L. (2003) Fundamentals of discourse theory. Moscow: Gnosis.

5. Kibrik, A.A. (2003) Discourse analysis in cognitive perspective: Unpublished Doctoral Dissertation. Moscow.

6. Gural, S.K. (2012) Discourse analysis in the light of synergistic vision. Tomsk: Publishing house of Tomsk University Press.

7. Arutyunova, N.D. (1990) Linguistic Encyclopedic Dictionary. Moscow: Nauka.

8. Karasik, V.I. (1998) About categories of discourse: Linguistic personality: socio-linguistic and emotive aspects. Volgograd: Peremena. p. 185-197.

9. Karasik, V.I. (2000) About types of discourse: Linguistic personality: institutional and personal discourse. Volgograd: Peremena. p. 5-20.

10. Makhnitskaya, E.Yu. (2002) About current economic discourse: Speech activity. Taganrog: TSPI. p. 158-161.

11. 中国新闻网.博鳌亚洲论坛开幕式习近平发表主旨演讲(全文). 中国新闻, 2015. Available from: http://world.people.com.cn/n/2015/0328/c157278-26764252.html (Accessed: 02.02.2016). 
12. 综合报道奇瑞汽车销售部副总经理秦力洪演讲. Available from: http://auto.sohu.com/ 20060628/n243986834.shtml (Accessed: 01.02.2016).

13. 大洋网-广州日报.卢布断崖式下跌中国出口企业很受伤. Available from: http://money. 163.com/14/1217/07/ADLCSCKN00253B0H.html (Accessed: 02.02.2016).

14. 中国经济网 . 金融者说：中国银行董事长田国立说新常态新思维. Available from: http://news.hainan.net/guonei/guoneiliebiao/2015/03/04/2278379.shtml

15. Kadimova, R.N. (2013) Business economic discourse as a form of institutional communication (for example, French). Bulletin of Moscow State Linguistic University. 10 (670). p. 51-61.

16. Komissarov, V.N. (1990) Theory of translation (linguistic aspects). Moscow: Highschool.

17. Fedorov, B.G. (1992) English-Russian Dictionary of monetary and credit terms. Moscow: Finance and Statistics.

18. 沈杰. 经济达人速成手册. 一世界图书出版公司北京公司. 2009. 47 页.

19. Schichko, V.F. (2004) Chinese. Theory and practice of translation. Moscow: East-West.

20. Kochergin, I.V. (2012) Fundamentals of scientific and technical translation from Chinese into Russian. Moscow: Eastern Book.

21. Vasilyeva, M.A. (2010) Official style of the Chinese language. Moscow: KARO.

22. Schichko, V.F. \& Yakovlev, G.Yu. (2012) Chinese. A full course of translation. Moscow: Eastern Book.

Information about the authors:

Malankhanova Antonina E., doctoral student at Moscow Pedagogical State University (Moscow, Russia). E-mail: duoniya@gmail.com

Sysoyev Pavel V., Ph.D., Ed.D., Professor, Head of Linguistics and Language Didactics Department at Derzhavin Tambov State University, Professor of the Department of Foreign Languages at Moscow Pedagogical State University (Tambov, Moscow, Russia). E-mail: psysoyev@yandex.ru 